DOI: 10.2478/pof-2018-0001

VOLUME 10, ISSUE 1, 2018

ISSN: 2036-5438

\title{
The past, present and future of the EU's federal experience
}

by

Francisco Pereira Coutinho and Martinho Lucas Pires*

Perspectives on Federalism, Vol. 10, issue 1, 2018 


\section{Abstract}

In 2017 we celebrated the $60^{\text {th }}$ anniversary of the Treaty of Rome and the $25^{\text {th }}$ anniversary of the Treaty of Maastricht. The commemoration of these historic events was the perfect excuse for a critical and renewed discussion of European integration. It was also an opportunity for discussing the EU through the lens of "federalism", i.e. to look at it from the perspective of federal theory and / or through its substantive and formal dimension. This issue of Perspectives on Federalism includes papers presented in conferences organized at Warsaw University in June 2016 and at Lisbon Nova Law School on May 2017 under the Jean Monnet Project "More EU - More Europe to Overcome the Crisis". The articles discuss, either from a more general or from a more specific standpoint, within a variety of subjects, some of the federal features of the EU.

Key-words

European integration, Treaty of Rome, Treaty of Maastricht, federalism 
The EU has been under severe strain over the last decade. The financial crisis that started in 2008, the war in Syria, and unprecedented waves of refugees that fled to Europe, as well as challenges to the rule of law in certain European States, and most recently Brexit, have all defied the ability of the EU to adapt and address problems of and in the Member States both effectively and fairly. The idea that the EU has been undergoing a "constitutional mutation", captures the importance of the moment well.

The issues that the EU currently faces are problems on a grand scale that are directly connected with the question of competences. They concern the nature, scope, distribution and justification of competences between the EU and the Member States within the European legal order: namely what kind of competence, how many competences, competences to who, and why. For example, in the "reformed" Economic and Monetary Union, is there too much centralization of budget control vis-à-vis the sovereign autonomy of Member States? Should there be a better distribution and burden-sharing of powers among States in the area of Freedom, Security and Justice to deal with increasing levels of migration? How should a European army be organized and financed? Or, in the case of other dimensions of the Economic and Monetary Union, where should the locus of the regulatory financial power lay — with the EU institutions or with Member States, or even with both?

Issues of competences, notably their distribution and management within supranational settlements, have long been discussed in academia within the conceptual framework of federalism. The EU itself has been characterized as 'a developed form of international organization which displays characteristics of an embryonic federation'. II This theoretical approach is very controversial; however, federalism is a concept that is part, for better or for worse, of the EU's normative history and that is firmly connected to its past, present, and future. ${ }^{\mathrm{III}}$

In 2017 we celebrated the $60^{\text {th }}$ anniversary of the Treaty of Rome and the $25^{\text {th }}$ anniversary of the Treaty of Maastricht. The commemoration of these historic events was the perfect excuse for a critical and renewed discussion of European integration. It was also an opportunity for discussing the EU through the lens of "federalism", i.e. to look at it from the perspective of federal theory and / or through its substantive and formal dimension. 
This issue of Perspectives on Federalism includes papers presented in conferences organized at Warsaw University in June 2016 and at Lisbon Nova Law School on May 2017 under the Jean Monnet Project "More EU - More Europe to Overcome the Crisis". The articles discuss, either from a more general or from a more specific standpoint, within a variety of subjects, some of the federal features of the EU: i) Samo Bardutsky critically engages public discussions and manifestos on the future of Europe on differentiated integration from the point of view of federal theory; ii) Tommaso Visone presents a historic research of the anti-federalist tensions at the heart of the Union to reveal a more complex scenario than what is currently perceived; iii) Matteo Bonelli analyses federal interactions and challenges between the EU and its Member States regarding the application of rule of law principles; iv) Rui Tavares Lanceiro draws a comparison between the EU and other federal systems, such as the United States and Germany, regarding the principle of sincere cooperation between national administrations when applying EU law; v) Sérgio Coimbra Henriques digs into the challenges that are ahead for the implementation of the federal capital markets framework; vi) Juliana Almeida and Guilherme Torrão Costa look at federal tensions and manifestations, from a historical and critical perspective, in European patent law; vii) Mariana Pinto Ramos discusses the difficulties of balancing different and conflicting interests between the Member States and the EU within the process of the European Social Dialogue; viii) Jacek Czaputowicz and Marcin Kleinowski look at how the voting system in the EU Council compares and differs from the voting systems in legislative bodies of other States; ix) Kamil Lawniczak explores issues of socialisation and legitimacy intermediation in the Council.

The articles present a diverse, thorough and profound perspective of federalism in the EU in several of its manifestations, and engage with the key question that the conferences set out to discuss: where are competences in the EU heading?

\footnotetext{
* Francisco Pereira Coutinho is Professor at Faculdade de Direito da Universidade Nova de Lisboa (Nova Law School) and member of CEDIS - I \& D research center for Law and Society. Martinho Lucas Pires is PHD Candidate at Faculdade de Direito da Universidade Nova de Lisboa (Nova Law School), member of CEDIS - I \& D research center for Law and Society and assistant lecturer at Faculdade de Direito da Universidade Católica Portuguesa (Católica School of Law).

I See Menéndez 2013 and Martinico 2016.

II Wyatt 2006: 132. See also Stein 1981 and Weiler 2001.

III See for example Schütze 2010 and Walker 2016.
} 
References

- Martinico Giuseppe, 2016, 'Le Implicazioni Costituzionali Della Crisi. Una Rassegna Della Letteratura', federalismi.it, no. 30, available at http://www.federalismi.it/document/29122016224815.pdf.

- Menéndez, Águstin José, 2013, 'The Existential Crisis of the European Union', German Law Journal, $\mathrm{XIV}(5):$ 453-526.

- $\quad$ Schütze, Robert. 2010, 'From Rome to Lisbon: 'Executive Federalism' in the (New) European Union', Common Market Law Review, XLVII(5): 1385-1427.

- $\quad$ Stein Eric, 1981, 'Lawyers, Judges, and the Making of a Transnational Constitution', The American Journal of International Law, LXXV(1): 1-27.

- Walker Neil, 2016, Federalism in 3D: The Reimagination of Political Community in the European Union, University of Edinburgh School of Law Research Paper Series, no. 13.

- Weiler J.H.H., 2001, Federalism and Constitutionalism: Europe's Sonderveg, Academy of European Law, 114, available at http://centers.law.nyu.edu/jeanmonnet/archive/papers/00/001001.html.

- $\quad$ Wyatt Derrick et al., 2006, Wyatt and Dashwood's European Union Law, $5^{\text {th }}$ edition, Sweet \& Maxwell, London. 